\title{
Sites and objects, indigenous library and the history of Laimbwe, Cameroon
}

\author{
Henry Kam Kah \\ University of Buea, Cameroon
}

\begin{abstract}
This study focuses on the construction of the history of the Laimbwe people of Cameroon through indigenous methods of enquiry and/or epistemologies. These include analyses of surviving historical objects, sites and artefacts from the pre-colonial period to the reunification of British Southern Cameroons with the Cameroun Republic in 196r. Some traditional items of the Laimbwe people of Cameroon and existing artefacts as well as sites reveal a very rich history with information that Western and conventional research have not vividly captured. In this paper, we reflect on the salience of these sources in understanding the rich socio-cultural and political history of the Laimbwe. There is a need to document this as an indigenous African library in this age of globalisation so that indigenous knowledge systems are disseminated to a wider academic audience. A construction of Laimbwe history through these indigenous forms of the library present them as new perspectives of local epistemologies beyond the capture of the western library introduced into Africa during the colonial period and even before. It continues to shape the way African national and local histories are written based on Western interpretations and or epistemologies.
\end{abstract}

Key words: sites, objects, history, Laimbwe, Cameroon

\section{Importance of Sites and Objects in History}

African scholars such as Zeleza criticise the suppression of African history through "epistemic violence of imperialist historiography." This dilemma of African history today is traced from Greek stories about Africa. The same was upheld by the colonial library and reflected in contemporary times. The colonial library consisted of the preservation of written material in archives or other public structures and the print media. This was regarded more or less as the only store-house of knowledge while other sources of knowledge acquisition like sites, objects and interviews were undermined. This contributed to radically silence or convert African discourses into western imposed perspectives. The result today manifests in erasures, omissions, fabrications and stereotypes about the history of the African continent. In response, African intellectuals have reacted with diverse intensities of epistemic domestication and defiance.

Africans have been reconstructing their histories through the collection of oral information about sites, objects, song and narratives of historical and cultural importance. In many rural parts of the continent there are historic sites which escaped documentation 
and preservation in the colonial library. Yet these are sources of information in understanding the history of migration, health, politics, settlement and the environment. The continuous reliance and projection of the "library with shelves" and the print media as the authentic sources of historical reconstruction, has unfortunately relegated the place of sites and objects as indigenous store-houses of knowledge. Some of these have only been considered useful for tourism and the generation of income for those promoting it.

Toponymy or place names are important in Africa because they contain valuable data for cultural, historical and archaeological reconstructions. In the continent a name is more than a mode of identification because it contains important aspects of the peoples' culture (Aleru 2010: 15I) and history including the large modern cities, which is not easily discernible by the public eye. Awolalu (1979: 36 ) observes that names of places in Africa form part of a peoples' vocabulary which give valuable information of a particular kind. This information contains important historical events about the community in which the toponymy is found. In fact, names of areas, roads, city squares and streets are often precipitated by incidences and provide background or are connected to information about the political, economic and social relations through which a thorough study of a people's culture and history could be carried out (Aleru 2010: 152). Maduibuike (1976) argues that names are important tools in recovering peoples' social habits and customs including also their hopes and aspirations. In a study of the urban area of Ijebu-Ode in Nigeria, Monin (1989: 44) observes that names of towns, cities and villages throw light on geographical, historical, religious and other aspects, and also various natural resources which attracted people to settle, and also how the settlement began.

Place names that become sources of historical reconstruction usually pave the way for a genuine understanding of among other things the topography of settlements and historical personages whose contribution to the establishment, development and stability of such settlements is enormous. A proper exploration in analysis and interpretation may convincingly lead to a coherent understanding of the history of development in a given area. This has and may enhance the cultural and historical reconstruction of a town, community or settlement. Toponymic studies can also be effectively used to provide a relatively chronological ordering of events in any given community (Aleru 2010: 153, 155 and $\mathbf{1 6 I}$ ) in Africa and elsewhere.

Again, culturally expressive forms, that is, both cultural practices and material objects can complement written records. This helps to offer fresh perspectives lost in the records themselves (Ebron n.d. http://nationalhumanitiescenter.org/serve/freedom/1609-1865/ essays/aaculture.htm, accessed on 13 December 2012). Gell (1998) opines that people think about the world through objects which, like human beings, have agency or serve an important purpose. The actual materiality of an object or artefact, argues Thomas (200I), sets limits on its social function, its production and its modification, through subsequent cultural transformation of value, through exchange and through its status as gift or commodity. Through the objectification fundamental theory which among other things focuses on the study of material culture, artefacts make it possible for one to understand the concept of knowledge and identity. Moreover, knowledge is also transmitted through 
the relation of things (Gell 1998). Gell further argues that an object has a certain agency of historical significance even if it is given a misinterpretation by some authors.

Not all objects are perceived to have a social life. This is because of a number of factors which include the cultural context, history and politics (Appadurai 1986; Kopytoff I986; Lubar and Kingery 1993; Thomas 2001). Objects become artefacts of interest as determined by their producers. In many cases, these artefacts are simply ignored. This is when they are considered not to possess agency that impacts upon or is bound up in their human counterparts. Ogundele (2006: 8) also argues that artefacts are silent and this has often led investigators to impose a system which is presumptuous of a universality ascribed to these artefacts.

In spite of this, an artefact is a document or thing that describes the past, whatever that past was. It is also an image that reflects the present and a sign that calls people to the future (Richardson 1989: 172). In explaining the importance of African pots to the people for example, Barley (2000) observed that pottery and female bodies and their powers are often associated with procreation and through them the history of procreation is understood or brought to light. The patterns used to decorate pottery mark the human body and the history associated with it. In this way, pottery becomes a medium through which people think about fundamental issues of life, death and social transformation. African pots constitute some of the most primary ways in which people and cultures make sense of an otherwise unfathomable world (Ebron n.d. http://nationalhumanitiescenter.org/ serve/freedom/1609-1865/essays/aaculture.htm). Such has been said about pots in the history of the Laimbwe people of Cameroon (Ngende 1966; Geary 1983).

The fading elements of many communities emit a faint glow of the rich historic past which was once presented by members of these communities. This explains why the United Nations Educational Scientific and Cultural Organisation (UNESCO) embarked on the preservation of sites of historic and socio-cultural significance through cross-cultural studies and exchanges; not only for the benefit of the societies concerned but also for the world (Pedersen 2002). In Louisiana in the United States in the I920s and I930s, there arose a cultural re-awakening among the local elite together with a few outsiders. This urge was stimulated by the strong interest in the fading elements of the bygone history of this city. These local elite observed that at the dawn of the 2oth century the physical remnants of the city's colonial and plantation pasts were visibly disappearing (Our Places, Our Heritage 2011: 14). They yearned for the revival and maintenance of the history of the city. This could effectively be done through the preservation of the remnants of the colonial and plantation pasts. The relevance of the plantations to the history of Louisiana indicates the importance of sites to the understanding and reconstruction of the past of any society including the Laimbwe of Cameroon. They have important sites through which their history can be constructed and/or reconstructed. The people of Louisiana through sites were able to evaluate where they were coming from and where they were heading.

Some objects and places were used in history to maintain peace, declare war or demarcate boundaries between different communities. In the kingdom of Kom in the North 
West of Cameroon in the pre-colonial period for example, two bundles, one of ash and the other of camwood were sent through special envoys to another chiefdom or fondom. If this fondom chose the bundle of camwood it was a sign of submission and acceptance of the status of tributary. If on the other hand this fondom chose the bundle of ash, it was an open invitation to war. Camwood was therefore a symbol of peaceful submission and ash symbolised warfare. In Bum still in the North West of Cameroon, the signal for war was given by the blast of an ivory horn of the chief. Two of these blasts called all to the chief's palace and three of them signalled the direction to be taken to fight the enemy (Nkwi 1987: 85). These are examples of the functions and history that lie behind objects like ash, camwood and ivory as used in Kom and Bum. The colonial library failed to capture the importance of these objects in terms of gaining a better understanding of the history of war, conflict and peaceful co-existence among ethnic groups in Africa.

On the other hand, African shrines were and are still cultural signposts which demarcate ethnic, territorial and social boundaries (Fomin and Ngitir 2011: 33). Through these places one can reconstruct the history of local boundaries and spheres of influence of ethnic groups in Africa. The importance of objects and places can effectively be valorised through a scientific investigation of the indigenous forms of keeping and using records for different historical purposes which are not confined in a library or stalked in shelves. This study examines this area of study that was neglected or not popularised by the colonial library in Laimbwe land of English speaking Cameroon.

\section{Objectives and method of study}

The objectives of this paper are two-fold; first we will show that sites and objects in Laimbwe land have remained neglected and unexploited by the administration and academic institutions as traditional forms of libraries or storehouses of knowledge. Secondly, the paper shows how these have been excluded from the modern library introduced by the German and British colonial administrations between c. I900 and I96r. By examining their historical relevance the paper shows that sites and objects are veritable African knowledge systems which should be incorporated into the modern concept of the library. If this is not done, the modern library will remain an incomplete storehouse of knowledge for researchers investigating different aspects of the history of objects and sites in Africa in the 2ist century.

The method used in this paper is rooted in the African knowledge system or base which is essentially orally handed down from generation to generation through various forms of interaction and not necessarily in a formal school setting. We spent several years in the field in Laimbwe land at regular intervals discussing sites and objects with people and how these were useful in filling gaps in the history of the people in particular and Cameroon in general. The discussion was carried out in the village square, the market, on the way to the farm, churches, death celebrations, special feast days such as cultural weeks and the Christmas and New Year seasons when many people are at home. At times we proceeded in a leisurely manner around firesides while roasting and eating maize. This was also carried out during other social gatherings which brought together men, 
women and the youth. In some instances, we simply visited and listened to elders talk just on almost everything about the village from the past to the present. These discussions and interviews were on a one to one basis and also in the form of focused group discussions.

Through free discussions and interviews therefore, much was said by the elders about the objects and sites that we finally selected for historical analysis. However we complemented our oral information with manuscripts and other written sources such as articles and books which were very difficult to come by. Above all, we took pictures to make visible the objects and sites we were examining as indigenous libraries to reconstruct the history of the Laimbwe people of Bu village which could not be built exclusively on the colonial library or forms of documentation.

\section{Fault lines of the Colonial Library in Africa}

The library is an integral component of the information system of a country or society. It provides a service or access to information (Buckland 1992) for the society. Libraries are usually established to meet information needs of academia, governance, industry and individuals especially in the western world. This institution occupies a central position in knowledge creation and innovation. Yet, it should be understood that a library is not only a number of books. Krause et al. n.d. (Knowledge Cities-Libraries in Africa." www.libraries-in-africa.com) maintain that a library is influenced by its environment and so it defines itself through the collections of knowledge for education, research and politics.

If the library is not merely a collection of books then it includes other forms of storing information that should be known and consulted to acquire holistic knowledge of any given people in the world. According to Banjo (1998), traditional intellectuals like elders, clan heads, priests, historians, storytellers and musicians constituted libraries or they were librarians in their own spheres. Since these categories of people were libraries in their own right, it re-enforces the notion that the library in pre-colonial Africa was essentially oral but it was also written as in the case of Egypt, Mali among others. Oladele (2008: 2) underlines the significance of the oral library by re-iterating the Kenyan saying that "the death of an elder is like a burning library." The celebrated African Historian Joseph Ki-Zerbo also contended that an old man that dies was an entire library burning down (Cited in Niang 2006).

The colonial libraries in Africa were developed on the basis of the western model of libraries and librarianship. The British for example were engaged in a wholesale transplanting of the library to Africa especially in Kenya. The aim of this scheme was to support the requirements of the mother country (Rosenberg 1993). The contention was also that knowledge and culture were primarily transmitted through the print media, although today it is increasingly transmitted through electronic means. The limitations of this kind of library include the exclusion of the rural population in many parts of Africa who are generally unable to read and write and are unaccustomed to print and have limited or no access to electronic media. It has also been shown that these libraries cannot 
play the role of information providers or adequate storehouses of African cultures and traditions rooted in the oral traditions (Nyana 2009: 9-10). Sturges and Neill (1998) argue that existing African libraries are not only foreign but were developed without modification or consultation with African communities. Alemna (1996) also points out the fault lines of the libraries that were set up in Africa during the colonial era. He notes that African libraries are trying to replace oral culture with reading culture instead of focusing on providing relevant skills and information necessary for rural communities.

The libraries set up by the European colonisers in Africa served a useful purpose but these did not succeed in capturing the histories of the local people because these libraries were built on western notions of record keeping. This explains why Chisita (2011:7) suggests the need for a return to the concept of "libraries without shelves or "oral librarianship" as a way of decolonising and demystifying library services in Africa. This has been used, but not in synergy. Through this, stakeholders of this kind of library will be helpful in the restoration of the once vibrant but threatened culture of Africa.

A study such as this which focuses on sites and objects in Laimbwe land in Cameroon relies heavily on a consistent presentation of oral information in understanding the history and culture of the people of Bu village which the library with shelves has failed to incorporate. If the colonial past of Africa or other parts of the world was vividly represented in material culture, monuments, architecture, libraries, archives and museum collections, dress and music (L'estoile 2008: 267), then the past of Africa prior to colonialism especially in terms of its sites and objects would be consciously studied and information collected, popularised and valorised for succeeding generations. The failure to study the history of these sites and objects or the deliberate ignoring of them in Laimbwe land and elsewhere for other ulterior motives will mean a failure to fully appreciate history which is buried in these visible things and forms of libraries.

\section{Locating the Laimbwe territory}

The Laimbwe ethnic group under study consists of mainly three kin-villages which include Baisso (Ebolisso or Ebuisso), Bu (Ghame'ehbouh or Eh'bouh) and Mbengkas (Bengka'ah or Eh'mbeka). Other subordinate speaking peoples associated with the Laimbwe are Aguli (Kekuli), Mughom and Mbongkessu (Kah 20Ir: 7I). Access to Bu, the gateway to Laimbwe land, through Wum, the headquarters of Menchum Division is after a twelvekilometre ride on motorbike (Bendskin) or a vehicle. One can also get into Laimbwe land through Mentang village to Baisso in Fundong sub-division of Boyo Division (See Map I). Bu is an important border settlement between Menchum Division on one hand and Boyo and Mezam Divisions on the other. Both Mbengkas and Baisso belong to Fundong sub-division, Boyo Division and Bu is part of Wum Central sub-division of Menchum Division (Kah 20II: 12). All three territories are in the North West Region of Cameroon which is one of the ten regions of the country and the only other English speaking region out of two.

The whole of Laimbwe is located within Latitude $60^{\circ} \mathrm{N}$ and Longitude $10^{\circ} \mathrm{E}$ (Kah 1998: 29). The location of the Laimbwe polities on hill and undulating slopes overlooking 
the Meteh-Menchum-Mughom River valleys and surrounded for most of the part by the Kom/Wum Forest Reserve makes for very interesting history of interaction between the people and the environment. Such interaction over time made it possible for different places to contribute to the understanding of the history of origin, migration, settlement, political organisation and governance among others of the Laimbwe villages. A good number of the sites and objects the people made use of and have kept or preserved were derived from this rich savannah forest and grassland ecosystem of the North West Region of Cameroon.

\section{Laimbwe sites and history}

The Laimbwe ethnic group has many sites of historical, political and socio-cultural importance. Among these sites or locations are Ghame'ehbouh $\mathrm{Bu}$, meaning 'we are tired'), Bengka'ah (Mbengkas, meaning 'our branching off road' or 'our branch'), Ebolisso for short Ebuisso (Baisso, meaning 'valley of vegetables'), Ngulekang (Nduokang lineage forest), Kezheh (god), Kuifekai (Hill of Eunuchs), Kulinaiwile (old town hill), Kule'Uzong (Hill of the Uzong lineage) and Ngohtebeh (camwood stones and also a quarter in Bu village). For the purpose of this study we have selected Ghame'ehbouh (Bu), Bengka'ah (Mbengkas), Ebolisso (Baisso) and Kezheh as sites for examination. This is because the story is fairly well told in historical narratives about these sites of historical importance in Laimbwe land. 


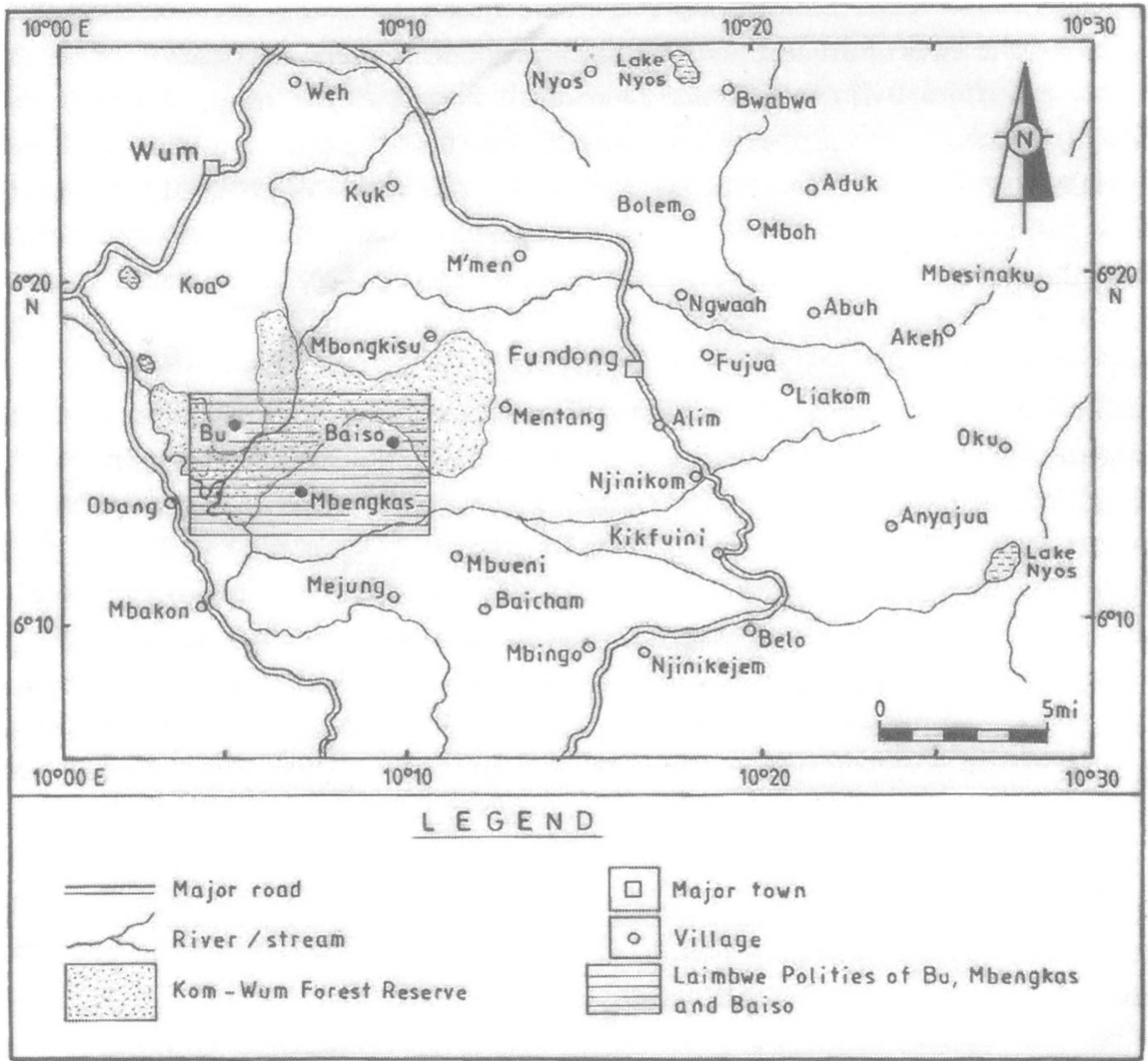

Map 1: A cross section of Menchum / Boyo divisions showing the Laimbwe polities.

The names of the three Laimbwe villages can best be understood by engaging in their history of migration, conflict, identity and separation. The name Ghame'ehbouh for short Eh'bouh literally translated means 'we are tired.' The modern name given to the settlement during the colonial era was Bu which is a corrupted and shortened form of 'we are tired.' Bengka'ah also known as Eh'mbeka when literally translated means 'branching off road' or 'our branch' and Ebolisso also called Ebuisso is translated to mean 'valley of vegetables." The history of migration of the Laimbwe people show that they came from

Interview with Rev ENG Cheng, Bu Road Wum, 20 March 1997. He was a retired pastor of the Presbyterian Church in Cameroon who before retirement had served in important positions of responsibility in the church including the Director of the Church Centre in Bamenda and Presbyterial Secretary of the former Menchum/ Boyo Presbytery; Interview with High Kaghesah, Bu, I March 1997. He was one of the longest serving lineage head of the Eselemei lineage and key member of the Kuiifuai regulatory society. This information is also given by many inhabitants of the three villages of $\mathrm{Bu}$, Mbengkas and Baisso. With regards to the history behind the name of Mbengkas, mostly elderly people male and female give precise information while many young people are ignorant. 
Ndobo, a region associated (though contested) with the migration of the Tikar speaking ethnic groups of Cameroon and settled for many years at Ndewum around Bafmeng in Fungom sub-division of Menchum Division. From here, they moved and settled at Esei (Isei) and then to Ipalim from where they split with another kin group of Kuk. They now moved south and westwards to settle at Mbuhndum and eventually Mba-ahzih, a flourishing road junction settlement within what became known as the Kom/Wum Forest Reserve which linked Laimbwe and other southern communities to Kom, one of the largest ethnic groups in Anglophone Cameroon. It was at Mbuhndum and/or Mba'ahzih that the Laimbwe group began to split because of lineage agglomeration, quarrels and disagreements (Kah 2012: 84-5) (See Map 2).

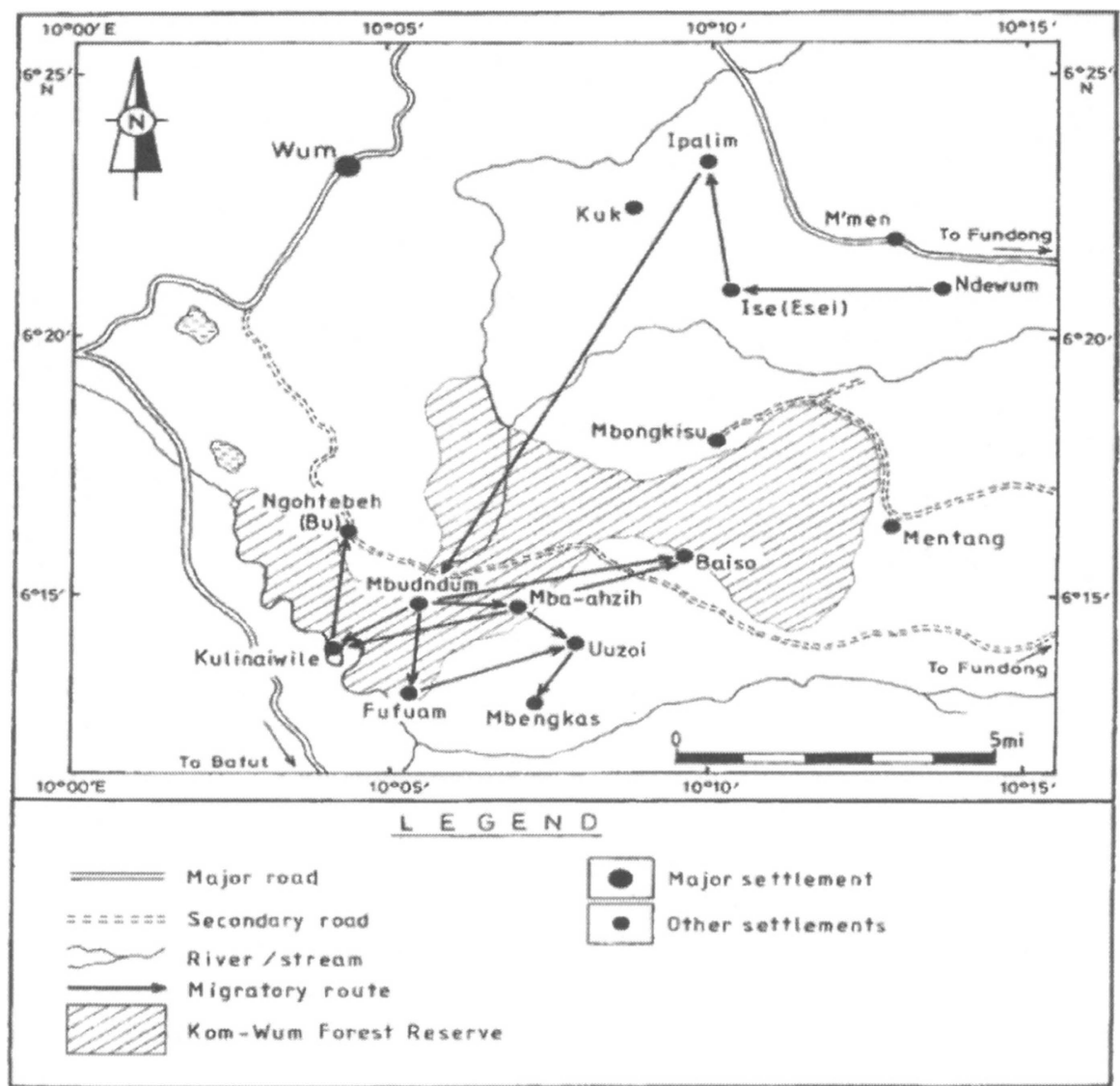

Map 2: Migratory routes of the Laimbwe ethnic group in the 18th \& 19th centuries. 
The separation of the Laimbwe people into the three kin villages around the 18 th century better explains the meanings of their place names. The Bu people crossed the River Meteh and found that they could not continue sine die because they were tired. Their settlement at Kulinaiwile (old town hill) was a result of being tired of migrating thus the origin of the name of the place Ghame'ehbouh or 'we are tired.' The Mbengkas people in the course of following their own path away from the main group got to be associated with Bengka'ah or 'branching off road' or 'our branch.' By so deciding and branching off their own way, they came to have the name associated with branching off or taking their own road towards their own direction. On the other hand the Baisso people moved away from Mbuhndum and also Mba-ahzih northwards where they found a valley with a lot of vegetables that grow in the wild and called their place name as ebolisso or 'valley of vegetables.'3

The colonial documentation and library popularised by the Germans and the British not only corrupted the original names and meanings of the Laimbwe villages but gave them a different appellation without any documentation as to the real meanings and origins of these names. Whenever mention is made of these three polities and reference is made to history, the story is narrated how and why these places came to be called. Without recourse to a library in places and the people's memory, it is difficult for anyone relying on library documentation on Laimbwe to know the actual history and meaning of these names. Such is an account of the meaning associated with the name of the Laimbwe villages and this in some instances also reveals the people common outlook to life. Today among the Laimbwe speaking villages, others commonly refer to the Mbengkas person as one who wants to go solo. If there is any truism in this opinion, it is best captured in the history of migration when Mbengkas people decided to break off from the rest of the Laimbwe group and take their destiny into their own hands.

Another important site which could be of great historical, socio-political and cultural importance in Laimbwe land is the Krehke'azheh (Kezheh forest) situated in the heart of Bu village and coincidentally very close to the forest of the Kuiffuai regulatory society. Both forests serve important political functions in the history of Bu village. The Kezheh forest is a grove made up of tall natural trees which have survived succeeding generations of Bu village. (See Plate $\mathbf{I}$ ). The forest is very rich in biodiversity and separates two quarters in Bu namely Mbulom and Tschistchouh and interestingly enough shares a boundary with the Presbyterian Church Bu which is against traditional rituals and forms of worship. In the Krehke'azheh the Esei stream takes its rise. It rarely goes dry even in the heart of the dry season and served the population of the neighbouring quarters at the heart of the dry season in the past when many streams dried up. This was prior to the development of potable water in $\mathrm{Bu}$ in the rggos. The stream continues to serve a useful purpose to the villagers living close to and not inside the Krehke'azheh. 
According to oral and historical narratives with regard to the founding and activities of Bu people in the Krehke'azheh or Kezheh forest, aspects of their history are brought to light but which have never been found in the available literature on Laimbwe history in libraries. Such aspects include environmental, health, conflict, lineage and political history of the Laimbwe people.

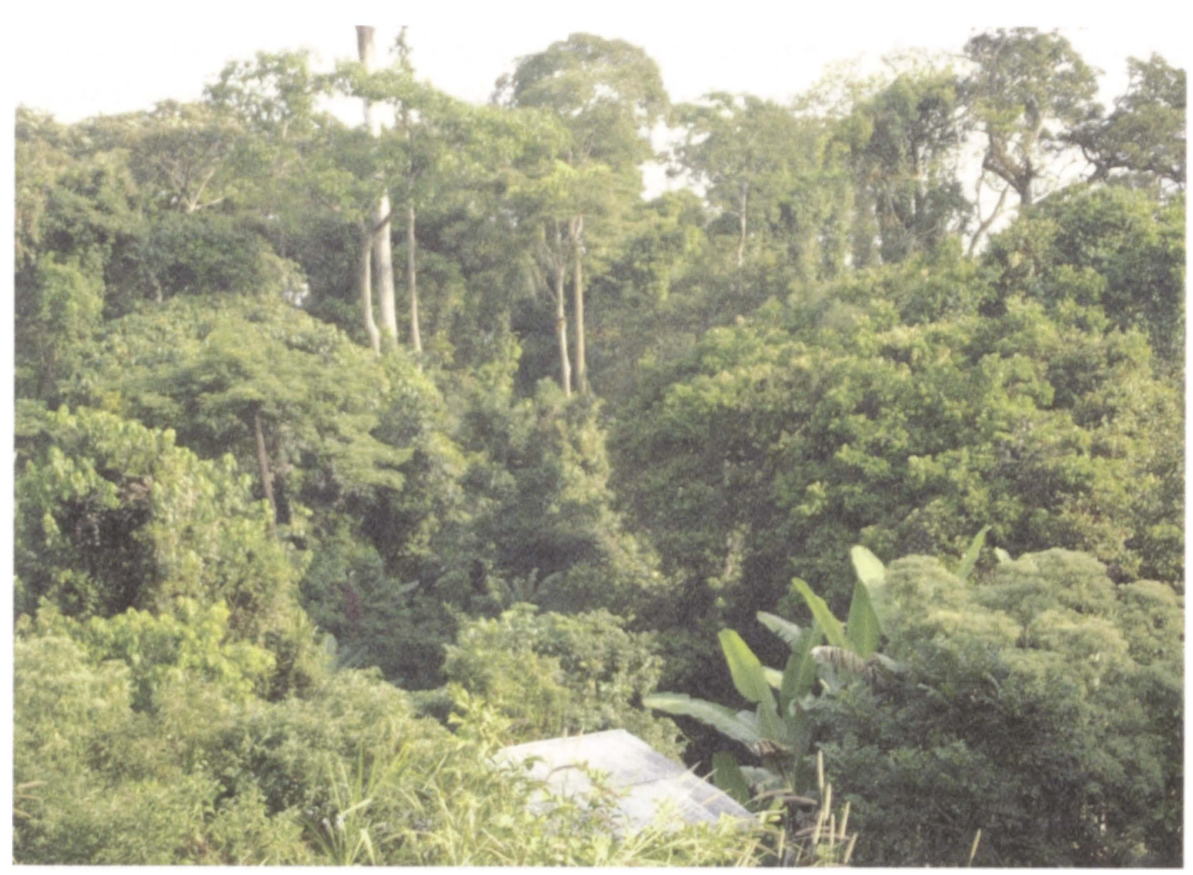

Figure 1: Northern view of the Krehke'azheh (Kezheh Forest) Bu, Cameroon (Source: author's collections 2012).

The Kezheh (god) is said to have come to Bu village from Befang in Menchum Valley sub-division through a woman. Oral narratives and a written source hold that when the Kezheh reached $\mathrm{Bu}$, it was given to the lineage head of the Ukwoazheh and Village Priest or Seer in the person of Tschonghe'ngei by the Fon and was asked to hide it in the Krehke'azheh or Kezheh forest for the security of Bu people. Since then, the Ukwoazheh lineage is associated with the ownership of the Kezheh forest. They have led the ritual activities associated with the forest since it became historically important between the last quarter of the rgth and early decades of the 2oth century. ${ }^{4}$ Although there is agreement on the place of origin of the Kezheh (god) and lineage bearer, there is no uniformity as to the Fon to whom the Kezheh was handed over by the woman from Befang. Amaazee (1964)

Interview with Timathias Ebuh, Bu, 28 December 2002 ; Dan Bughe Bei, Bu, 23 December 2007; James Ambei Kamkoh, Bu, 28 December 2007; Andreas Kom, Bu, 7 March 2008; Ngoisey, Bu, 23 December 2008; Victor Bong Amaazee, "The Traditional History of Bu, Wum Division," 1964, File No. 3082, Presbyterian Church in Cameroon Central Archives and Library (PCCCAL), Buea. 
and Abel Kpwai' ${ }^{5}$ argue that the fon at the time was Bonghezee but Kpwai Ekai ${ }^{6}$ argues that the Village Seer was son of Fon Sa-ah Ngwo (Kpwe Wei) and the Kezheh was handed over to him by the father and not Bonghezee who succeeded Sa-ah Ngwo under controversial circumstances. Those who support the view that the Kezheh was handed over to Tschonghe'ngei by Bonghezee argue that the former was a son-in-law of the latter.

In spite of the differences over the Fon who handed the Kezheh to the head of the Ukwoazheh lineage for safekeeping, there is unanimity on why it was an Ukwoazheh lineage head who was handed the Kezheh. The reason is that this was assumed as a lineage of witches, wizards and magicians. The village elders believed that only such lineages could be mandated to handle delicate matters such as the Kezheh or god brought in from Befang village. It can also be argued that since sons played an important role in the history of the Laimbwe people the Kezheh was most probably handed over to Tschonghe'ngei by Sa-ah Ngwo his father for safe-keeping. He ruled Bu village from c. 1900 to 1925 . After his death he was succeeded by Bonghezee (Kah 2012: 146). In addition, historical narratives are unanimous and have generally agreed that the Kezheh (god) was brought to Bu village much earlier than 1925 when Sa-ah Ngwo (Kpwe Wei) died and Bonghezee succeeded him. This is further supported by the fact that ritual activities of the Ikuum lodge of the Kuiffuai regulatory society led by the Eselemei and Ehzem lineages are performed in the Kezheh forest to this day. This ritual in the Kezheh forest or Krehke'azheh was never performed by any other lineage except the Eselemei, Ehzem and Ukwoazheh. If it was Fon Bonghezee who handed the Kezheh (god) to the Ukwoazheh lineage head, his Uzong lineage would certainly have also performed the Ikuum ritual in the Kezheh forest but it has never.

The historical narratives linked to the Krehke'azheh (Kezheh forest) also show that the Laimbwe people protected the environment and especially the forest from destruction. This is a positive aspect as far as environmental history is concerned. The felling of trees and hunting in the Kezheh forest were and remain a taboo in Bu village. Those who attempted to do so as recently as the first decade of this century invited a swarm of bees from the forest to sting people in the neighbourhood. ${ }^{7}$ The situation was brought under control when rituals were performed by the people to appease the god or Kezheh considered to be residing in this forest. The fact that bees stung people because a tree was cut in the Kezheh forest very recently has only validated the claim that there are mystical forces in this forest. Modern methods of forest or environmental preservation need to borrow from the indigenous methods to be more accommodating and successful.

The harvesting of fuel wood for home use is also forbidden in this forest although it is located at the heart of the village. The organisation of initiation rituals for new members into the Ikuum lodge of the Kuiifuai regulatory society in this forest from time to time made it impossible for anyone to embark on deforestation in the Kezheh forest. In the foreseeable future the forest is unlikely to be destroyed because of its historical,

5 Interview with Abel Kpwai Embou, Ndop, 27 December 2012.

6 Interview with Joseph Kpwai Ikai, Bu, 28 December 2012.

7 Ibid. 
socio-cultural and communal significance. Abel Kpwai Embou, quarter head of Toni quarter and elderly Christian of the Presbyterian Church in Cameroon, contends that the Krehke'azheh has not and will likely not be cleared because "it is the hiding place of Bu." ${ }^{8}$ his simply means that, the forest is the soul of the people and cannot be destroyed by them since it will affect them negatively. The ritual performed in the Krehke'azheh is not opened to public view. It is conveniently performed in the confines of this forest which explains why it has not been destroyed among other reasons. While this forest has long been preserved, the Kom/Wum Forest Reserve located within Laimbwe land has come under intense deforestation for farming and other related activities.

Again, the continuing existence of this forest and the history associated with it shows that it contributed towards enriching the health history of the Laimbwe people. The Village Seer and head of the Unkwoazheh lineage performed rituals in the forest in the past to help cure diseases in Laimbwe land. He collected water from the forest in a small calabash. This was used in bathing children to prevent them from contracting ailments during the dry season. Adults also used the water in washing their faces, hands and legs for the same purpose and to purify themselves. This ritual was performed by Tschonghe'ngei and when he died, the successor Ndongyam continued with this cleansing and ailment prevention ritual. It was after his passing into eternity that a tussle for succession in the lineage erupted and resulted in the usurpation of the throne by Fosi Beng Ikai from Mbai who was rightfully the next lineage head of the Ukwo'azheh. Since Beng Ikai usurped the headship of the lineage, he was not introduced to the medicines needed for this calabash ritual by a son of the lineage. ${ }^{9}$ Although this ritual is no longer performed, the ritual of initiation of Ikuum members which takes place in the Kezheh forest has survived to this century. It is believed to serve a useful purpose of assisting the health service from keeping the villagers secured from ailments because the ritual involves cleaning the village paths and compounds. Sites like the Kezheh forest therefore provide useful information about the evolving health history of the Laimbwe people of Bu.

The history of governance in Laimbwe land is made possible by explaining the role of the Kezheh and Kezheh forest in the history of the people. Two principal lineages of Bu namely Ehzem and Eselemei draw their power and influence in village affairs from their leadership of the ritual of initiation of new members into Ikuum lodge of the Kuiifuai regulatory society which is performed in the Kezheh and Kuiifuai forests. The god or Kezheh in the Krehke'azheh is presented the candidacies of elders for approval or disapproval. Some people are rejected mainly on the basis of disunity in their families and also because of their poor behaviour in public. ${ }^{10}$ The newly initiated, most of them from the two leading

Interview with Abel Kpwai Embou, Ndop, 27 December 2012.

Interview with Vida Wei, Bomaka, 16 December 2012.

I0 Interview with Nathaniel Akou, Bomaka Buea, I3 December 2012. He is a retired teacher and former First Assistant Mayor of the Fundong Rural Council. He hails from the Laimbwe village of Mbengkas and witnessed the ritual activities performed in the Kezheh forest as a pupil in primary school in Bu in the early I960s; Interview with James Ambei Kamkoh, Bu, 14 August 2007 and 28 December 2007. He died some years back, was quarter head of Bafren and leading member of the Kuiifuai regulatory society of Bu village. 
lineages define and oversee the implementation of policy in the village. In fact, members of Ikuum, the apex lodge of the Kuiifuai regulatory society are power brokers in village administration (See Plate 2 for the Kuiifuai forest).

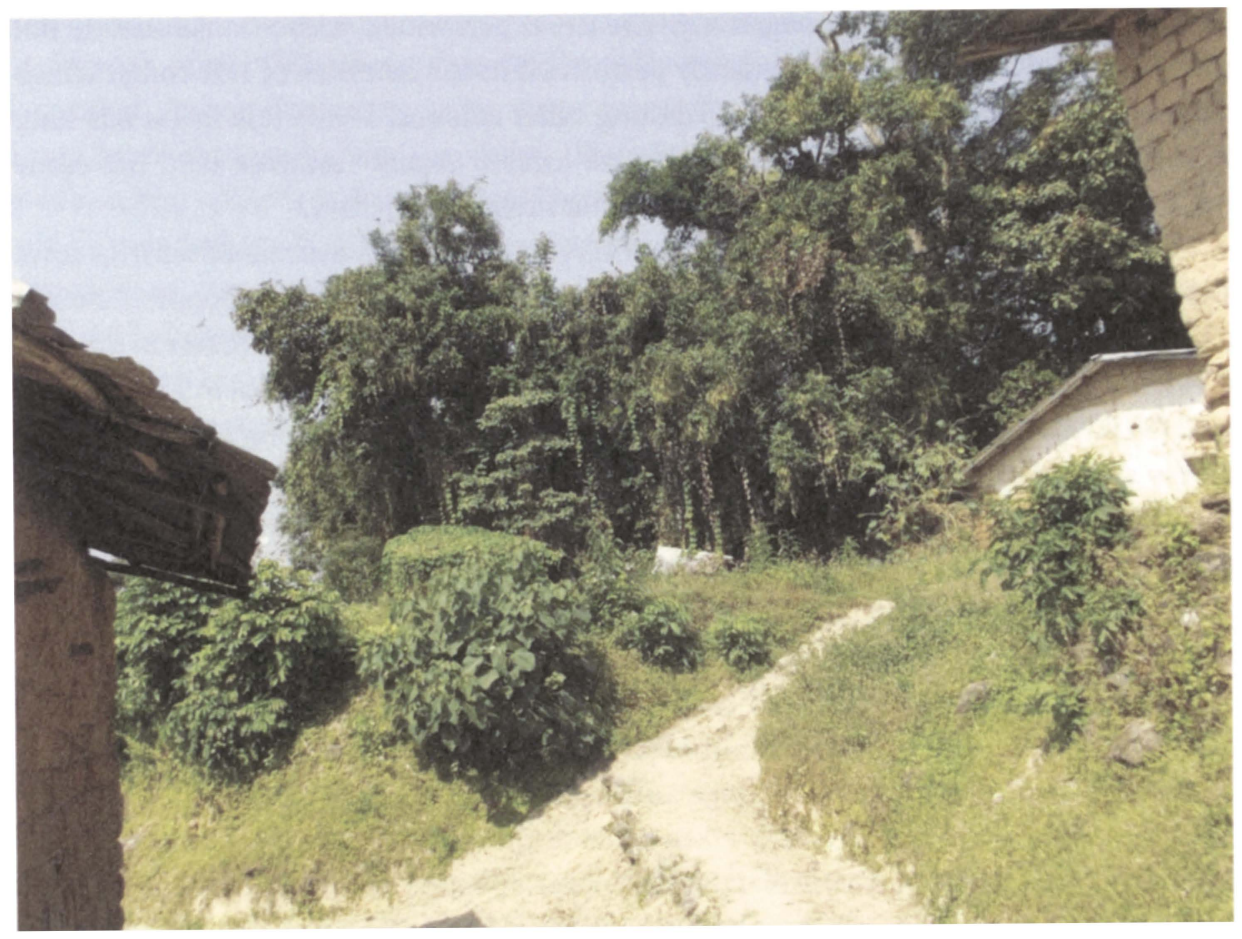

Figure 2: Partial view of the Kuiifuai Forest, Bu Cameroon (Source: author's collections 2012).

The communal history of the Laimbwe people is presented in the historical narratives of the Kezheh forest or Krehke'azheh, an indigenous library or storehouse of knowledge which was not fully captured in the colonial library in Cameroon set up by the Germans and the British. Prior to and during the colonial period, collective hunting, or ehbwe'azheh (hunting for god) was organised. After several days or weeks of hunting, the catch was brought home, boiled and distributed among women and men. A quantity of this meat was given to the Kezheh (god) in the Kezheh forest. This was to plead with the god to deliver a message or foretell something of importance and peace to the people. The message usually included the importance of living together and for debtors to honour their engagements with their creditors. Following the advice of the Kezheh, debtors were called by the village elders and told to pay their debt to their creditors and maintain the peace of the community." 
Similarly the initiation ritual of new members into the Ikuum lodge was preceded by the boiling of local specie of beans known as eh'sang by a woman of the Ukwoazheh lineage or a child of that family. The ritual usually brought together everyone to share in the meal and discuss issues of the collective interest of the population. ${ }^{12}$ The narratives of collective hunting, preparation and consumption of eh'sang showed that Laimbwe communal history was promoted by those ritual activities that were associated with the Krehke'azheh. Although collective hunting is no longer pursued today because of growing individualism, there is still the ritual of preparing beans or eh'sang for consumption by the people who gather together and this has enriched the communal history of the people.

The settlement of disputes or resolution of conflict is a theme that emerges from the historical narratives of the Kezheh forest of the Laimbwe people of Bu. Conflicts were settled at various levels through different mechanisms using the Krehke'azheh. Whenever the Ukwoazheh Priest or Village Seer was asked to visit the forest and 'talk' with the Kezheh, it was because of impending conflicts of different kinds. The visit often led to the resolution of conflicts which included those between lineages and individuals. When the Priest returned with information about an impending conflict in the village, this was professionally handled by the elders. When some elders were rejected by the Ikuum lodge it was mostly on the basis of conflicts within their lineages and they were admonished to help solve them if they wanted to join or be admitted into this society.13

The revelation by the Ikuum from the Kezheh forest contributed to the resolution of conflicts or feuds in different lineages. It also gave rejected members the hope that they could be admitted later on when the Ikuum appeared in the village from the Krehke'azheh. Conflicts in Laimbwe land that were also associated with the introduction of ailments by evil forces were handled in the Beisaghekeh or compound where matters were settled following ritual activities in the Krehke'azheh. This gathering of people to discuss village issues was often at the instant of the Ikuum within the kuiifuai regulatory society and recruitment of new members. The history of conflict and resolution in Laimbwe land is partly understood against a backdrop of the central role of the Krehke'azheh which was unfortunately absent in the literature of the colonial library concerning the Laimbwe country. Apart from the sites, objects are also a library from which the history of Laimbwe can be constructed and/or reconstructed.

Interview with Rtd. Rev Simon Muam Asang, Bu, 8 January 2007. He is a retired pastor of the Presbyterian Church in Cameroon and one of the oldest surviving Laimbwe persons; Interview with Grace Ndzjuh, Bomaka Buea, 16 December 2012. She is a daughter of Ndanghe Zhee, an important village elder and deceased leader of the Kuiifuai regulatory society; Interview with Ngoisey, Bu, 23 December 2008. She was one of the leaders of the Kefa'a women regulatory society in Bu village.

13 Interview with Andreas Kom, Bu, 20 August 2007; 7 March 2008 and 29 December 2012; Interview with Vincent Kpwa, Bu, 28 December 2012. Both are members of Ikuum, the apex lodge of the Kuiffuai regulatory society and lead the rituals of initiation into this lodge today. 


\section{Objects and Laimbwe history}

In Laimbwe land there are several surviving objects through which one can construct and/or reconstruct the history of the Laimbwe people from the pre-colonial period to independence. These objects and or artefacts include Ngohtebeh (camwood stones), Kieke Zheh'abei (family head's stool), Wua Zheh'abei (family head's ritual cup), Nguuh (wooden gong), ngeem (iron gong), Kekunghe (bowl made of spear grass), Isem (an elongated container made of spear grass), Phesooi (clay bowl), Tooi'tscha (clay pot). ${ }^{14}$ We have chosen $\mathrm{Ngohtebeh}$ for analysis and tried to show how this serves as an indigenous library or source for the reconstitution of the history of the Laimbwe people of Bu. Camwood was and remains an important product for socio-cultural use not only in Laimbwe land but also the entire grasslands of Cameroon and forest communities especially those of the Cross River region of Cameroon and Nigeria where much of the product is obtained from the camwood tree (Kah 2012b).

Ngohtebeh (camwood stones) which coincidentally is also the name of one of the first quarters in Bu where the people settled by mid-rgth century after their sojourn at Kulinaiwile (old town hill) (Kah 2012: 86) has contributed to understanding the socio-cultural history of the Laimbwe people of Bu. On these stones women were grinding camwood. ${ }^{15}$ This was harvested from the Laimbwe forest which was constituted into the Kom/Wum Forest Reserve by the British colonial government in the r93os. Due to the scarcity of camwood because of the regulation of illegal felling of trees in the Kom/Wum Forest Reserve by the colonial authorities, the people bought camwood from other parts of the grassfields of Cameroon and also from the Cross River region of Cameroon and Nigeria.

There were several of these Ngohtebeh (camwood stones) on which women spent time grinding camwood for various uses (See Plate 3 ). This precious commodity was a status marker and prestigious to have by those who were members of different traditional institutions that made use of the material. Following the initiation of new members of the Ikuum lodge of the Kuiifuai regulatory society in the dry season, they were rubbed with camwood. This was first preceded by an announcement from the Ikuum message bearer that women should boil water early the following morning and have their husbands thoroughly washed. These initiates were then rubbed at the Beisaghekeh by their wives and children. The rubbing with camwood was followed by the wearing of beads around the necks of these men of substance and influence. ${ }^{16}$ Camwood was also used

14 In our many visits to the field we were told the historical significance of many of these objects by the following persons Joseph Nyamngoh, Metika Ndeh, Dan Bughe Bei, High Kasaghesah, Timathias Ebuh and Vida Wei.

15 Interview with Vida Wei, Bomaka Buea, 17 August 2007 and 16 December 2012; Interview with Grace Ndzjuh. Bomaka Buea, 16 December 2012; Interview with Ngoisey, Bu, 23 December 2008. Ngoisey grew up to witness elderly women grind camwood. This is especially so because she was living at Ngohtebeh where the activity was carried out drawing people from different quarters in the village and from beyond.

16 Interview with Andreas Kom, Bu, 20 August 2007; 7 March 2008 and 29 December 2012. Interview with Vincent $\mathrm{Kpwa}, \mathrm{Bu}, 28$ December 2012. Both men were explaining just what happened to them when they were initiated into the Ikuum lodge and the things their wives and children did to them. They explained that initiation would never have been complete if this camwood activity was not carried out. They are both leading Priests of the kuiifuai regulatory society and the second is the village chief charged with blessing of seeds, fertility and security. 
to rub men who were admitted into the Tschong (friction drum) society. ${ }^{17}$ This was also a society of mettle among the Laimbwe notables some of whom were also members of the Kuiifuai regulatory society. Camwood was therefore used not only to decorate these men of honour within the traditional society but it was also used to give authority to those who became members of the highest decision making institution in the village.

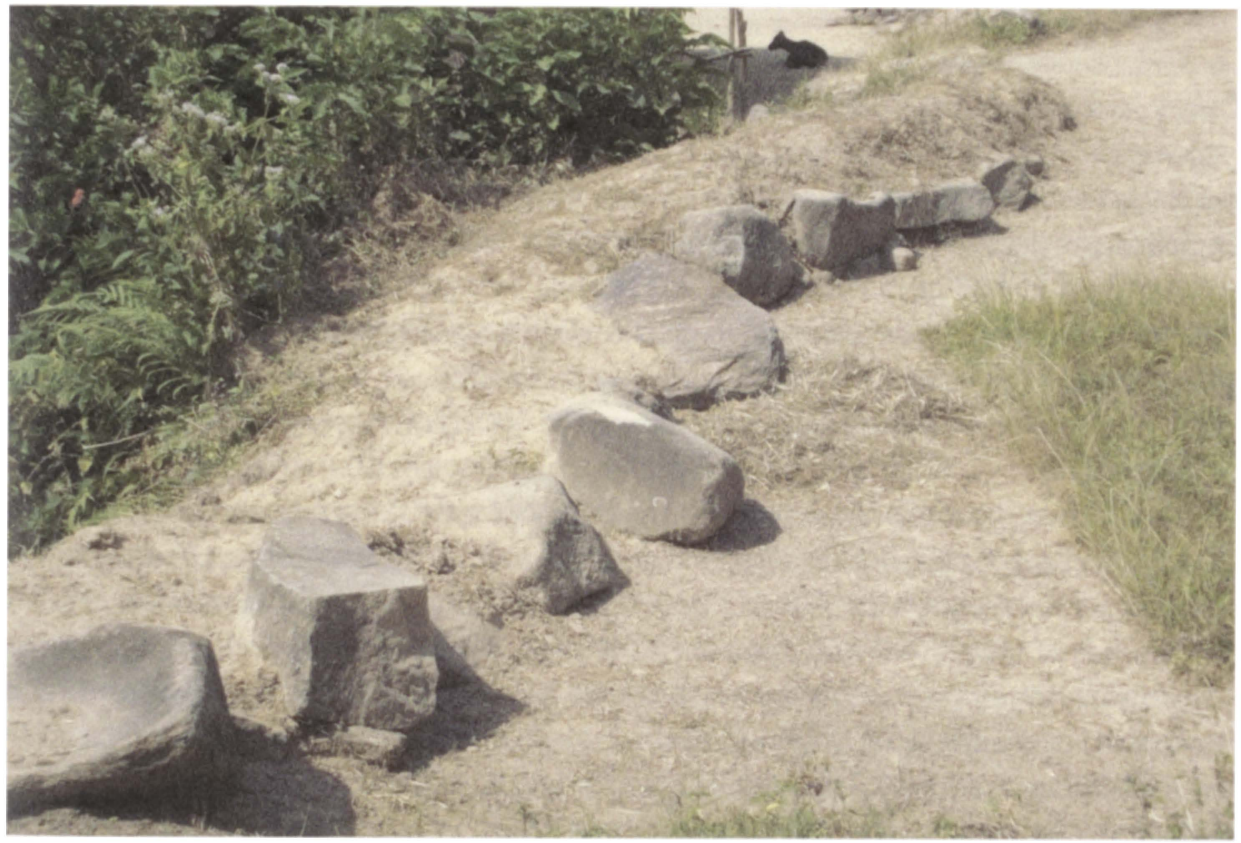

Figure 3: Some Ngohtebeh (Camwood Grinding Stones) Bu, Cameroon (Source: authors collection 2012).

Apart from rubbing men of honour and prestige who became members of the Ikuum and Tschong societies, camwood was also kept to rub members of the Kefa'a women regulatory society. Apart from rubbing them when they joined the society, these members also rubbed camwood on their heads, hands and legs when they performed during the funeral of a member or when an important government personality like the District Officer came visiting the people for meet the people tour or other reason..$^{8}$ More of the camwood was therefore ground into powder form and kept in the houses of members of this women's

17 Interview with Teacup Ndong, $\mathrm{Bu}, 29$ December 2012. He is one of the oldest Laimbwe persons and owns a Tschong. Most of the initiation activities of the members of this society are performed in his shrine. This elder is also a key member of the Ikuum lodge of the Kuiifuai regulatory society. It is through him that announcements are officially made about the death of a member of the Kuiifuai regulatory society. When he has been contacted, a younger person accompanied by another one can then move to the Kuiifuai forest and play the Nguuh or wooden gong to announce the passing away of a member. It is only after this has been done that people are permitted to cry the dead failing which they pay a fine.

18 Interview with Joseph Kpwai Ikai and Ndang Ebenezar Fung, Bu, 28 December 2012. These are all members of the Kuiffuai regulatory society in Bu, Cameroon. 
regulatory society for use in the future. Today, a son-in-law commands respect from the family of the wife if he purchases some camwood, a precious and scarce commodity and hands it to the mother-in-law for use at important occasions.

Camwood was also used as rubbing oil to keep Laimbwe people warm. This was because they did not have western style dresses in the pre-colonial and part of the colonial periods but for a few notables who used it to cover their genitals recta. ${ }^{19}$ During the early days, people did not have western styled dresses and wore mainly barks of trees and other local materials. Camwood was therefore bought and used to keep people warm against the biting savannah cold. Some Laimbwe women were provided with camwood as a smoothing device which would enhance attractiveness in preparation for marriage. In some instances, nursing mothers were rubbed with camwood to prevent men from taking them to bed until such a time as the child was a grown up. Camwood therefore prevented nursing women from unwanted pregnancy and assured the proper upbringing of children.

In the post-independence period when the Ngohtebeh (camwood stones) were no longer used for grinding camwood or kebheh, the stones were used in the settlement of disputes among people. The councillors were mostly notables from the principal lineages including the Ehzem, Eselemei and Ukwosuuh. They sat on these stones to dispense justice and unite the $\mathrm{Bu}$ people. When Chu Mbonghekang became fon of $\mathrm{Bu}$ in 1942, he eventually nominated quarter heads as members of the council. ${ }^{20}$ These stones declined in importance subsequently because the village grew and another location in the palace was designated. Today the remains of the Ngohtebeh are used only in the drying of tobacco, for rest and decoration. At the sight of or when mention is made of these stones, a whole history is narrated about it which enriches the socio-cultural history of the Laimbwe people in particular and Cameroon in general. These stones are therefore a form of indigenous library for the Laimbwe people. The colonial library could not capture nor keep track and record of this traditional library.

\section{Concluding remarks}

In this paper, we have tried to show that sites and objects are sources of information for history. Place names and objects are rich in history of the communities in which they are found. There is a history to their very existence. In spite of this, these were largely not given the attention they deserved in historical reconstruction by the German and British colonial authorities. This was compounded by the establishment of an educational system and preservation of documents and knowledge based essentially on western epistemological foundations. Their knowledge of the library was mainly limited to the books

I9 Interview with Andreas Kom, Bu, 29 December 2012. He is leader of the Ikuum and performs the ritual of initiation of new members today at the Kezheh grove together with other elders of the Ehzem and Eselemei lineages. 
and other forms of material which were produced and distributed from the West to the African continent.

In the Laimbwe polities of Cameroon, there are many sites and objects that have long survived and through them we can construct and/or reconstruct the history of $\mathrm{Bu}$ within the general history of the North West Region of Cameroon. These place names and objects in the Laimbwe country have a long history which is usually recounted in historical narratives by the people of this ethnic group who know these places and objects. In spite of this, research on these people has by commission or omission not exploited these local libraries or sources for the historical reconstruction of the Laimbwe people. There is therefore need for these sites and objects to be studied within the context of the history of the entire Laimbwe ethnic group which consists of $\mathrm{Bu}, \mathrm{Mbengkas}$ and Baisso villages.

The general lesson that can be learnt from this paper is the fact that the colonial library which has survived post-independence governments is limited in scope basically because of the western notion of the library as a storehouse for all knowledge. The library is an integral component of the information system of a country or society. It is also not merely a collection of books but include other forms of information storage of historical importance. For this reason, sites and objects contain information of historical importance that can enrich the historiography of different African communities. In short, much of the history of many places is buried not in the shelves but in the physical endowments that they have. Until the post-independence concept of a library changes and steps are taken to popularise detailed histories through objects which are not bought and displayed but kept in their natural environment, then a lot of the material we need for research from the libraries and archives will remain unexploited and untapped. This essay has thus selected a few of these to demonstrate that there is more to the history of the Laimbwe people through sites and objects than meets the eye. It is therefore high time that the Cameroon government build on the history of origin, migration, conflict, disagreement and separation of ethnic groups in terms of what the local non-confined libraries offer.

\section{References}

Alemna, A.A. (1996). Issues in African Librarianship. Accra: Type Co.

Aleru, J.O. (2010). "Towards a Reconstruction of Yoruba Culture History: AToponymic Perspective." African Study Monographs, Vol. 31, No. 4, pp. 49-162.

Amaazee, V.B. "The Traditional History of Bu Wum Division." 1964, File No. 3082, Presbyterian Church in Cameroon Central Archives and Library (PCCCAL), Buea.

Appadurai, A. (1986). The Social Life of Things. Cambridge: Cambridge University Press.

Awolalu, J. A. (1979). West African Traditional Religion. Ibadan: Onibonoje Press and Book Industries.

Barley, N. (2000). "West Africa-Pottery." Africa: Arts and Cultures (ed). Mark J. British Museum Press.

Banjo, G. (1998). Libraries and Cultural Heritage in Africa. IFLA Journal, Vol. 24, No 4, 1098: 228-232.

Buckland, M. (2003). Redesigning Library Services: A Manifesto. URL:

http://www.sunsite.berkeley.edu./literature/library/redesigning.hlt, accessed on 20 December 2012. 
Chisita, C. T. (201r). "Role of Public Libraries in Promoting Literacy in Zimbabwe: Challenges of Sustainability a Reading Culture." World Library and Information Congress: 77th IFLA General Conference and Assembly, Puerto Rico, 13-18 August.

De L'estoile, B. (2008). Introduction: The Past as it Lives Now: An Anthropology of Colonial Legacies. Social Anthropology, Vol. I6, No. 3: 267-279.

Ebron, P.A. (2012). "Beyond the Written Document: Looking for Africa in African American Culture." Freedom's Story, TeacherServe@. National Humanities Centre, 13 December 2012. http://nationalhumanities center.org/serve/freedom/1609-1865/essays/aaculture.

Fomin, E.S.D. and Ngitir, V.S. (20Ir). "Rituals in Traditional Boundary Settlements in the Cameroon Grassfields." In Boundaries and History in Africa: Issues in Conventional Boundaries and Ideological Frontiers (Festchrift in Honour of Verkijika G. Fanso (eds). Daniel Abwa, Albert-Pascal Temgoua and Willibraod DzeNgwa. Department of History, University of Yaounde I. pp. 32-43.

Geary, C. (1983). Things of the Palace: A Catalogue of the Bamum Palace Museum in Foumban (Cameroon). Wiesbaden: Franz Steiner Verlag/GMBH.

Gell, A. (1998). Art and Agency: An Anthropological Theory. Oxford: Clarendon.

Kah, H.K. (1998). "Local Government and Nation-Building in Wum Division 1949-72: A Historical Analysis." M. A. Thesis, University of Buea.

Kah, H.K. (20II). "The Cutlass my Husband, the Hoe my Wife: Women and Economic Development among the Laimbwe of North West Cameroon in Contemporary Times." KALIAO: Revue pluridisciplinaire de l'Ecole Normale Supérieure de Maroua (Cameroun), Vol. 3, No. 5, 2011, p. 9-22.

Kah, H.K. (2011). "Women's Resistance in Cameroon's Western Grassfields: The Power of Symbols, Organisation, and Leadership,1957-1961." African Studies Quarterly, Vol. 12, Issue 3, pp. 67-91.

Kah, H.K. (2012). Gender and Matriliny in the Laimbwe History, Cameroon, c. 1750-2001." PhD Thesis, University of Buea, Cameroon.

Kah, H.K. (2012). "Camwood (Pterocarpus Tinctorius) in the Political Economy of the Cross and Manyu Rivers Basin of Cameroon and some Hinterland Communities, 1916-61." Afrika Zamani, Vol. 20, pp. 149-164.

Kopytoff, I. (1986). "The Cultural Biography of Things: Commoditisation as a Process." The Social Life of Things (ed). Appadurai A. Cambridge: Cambridge University Press.

Krause, B., Liebscher, R. and Mörike, T. (N.d). "Knowledge Cities-Libraries in Africa." www.libraries-in-africa.com, accessed on 19 December 2012.

Labi, K.A. (2006). "Cross-Cultural Appropriation of Regalia and Royal Art, and Contemporary Adaptations in Ghana." Irene Odotei and Albert K. Awedoba (eds.) Chieftaincy in Ghana: Culture, Governance and Development. Accra: Sub-Saharan Publishers. pp. 275-294.

Lubar, S. and Kingery, D.W. (eds). (1993). History from Things: Essays on Material Culture. Washington D.C. and London: Smithsonian Institute Press.

Maduibuike, I. (1976). A Handbook of African Names. Washington D.C.: Three ContinentPress.

Momin, K.N. (1989). "Urban Ijebu-Ode: An Archaeological, Topographical and Toponymical Perspective." West African Journal of Archaeology, Vol. 19: 37-50.

Ngende, E.E. (1966). Geography of West Cameroon. Victoria: Basel Mission Printing Press.

Niang, A. (2006). "Joseph Ki-Zerbo: The Historian and his Struggle." http://www.pambazuka.org/governance/joseph-ki-zerbo-historian-and-his-struggle, accessed on I8 July 2016.

Nkwi, P.N. (1987). Traditional Diplomacy: A Study of Inter-Chiefdom Relations in the Western Grassfields, North West Province of Cameroon. Department of Sociology, University of Yaounde.

Nyana, S.A. (2009). "Creating a Library System that Serves the Needs of Rural Communities in Africa South of the Sahara." The Journal of Pan African Studies, Vol. 3, No. 1, pp. 9-22.

Ogundele, S.O. (2006). Prospects and Challenges of Oral Traditions and Ethnography for Archaeological Reconstruction: A Case Study of Tivland, Nigeria. Anistoriton Journal, Vol. 1o Section Viewpoints Vol 6r:1-13. 
Oladele, B.A. (2008). "Globalisation and African Libraries: The Challenge of Self-Discovery in a Digital World." World Library and Information Congress: 74th IFLA General Conference and Council, Quebec, Canada, 10-14 August.

Our Places, Our Heritage: A Plan for Historic Preservation and Archaeological Conservation in Louisiana, 2011-2015. Louisiana Office of Cultural Development, January 2011.

Pedersen, A. (2002). Managing Tourism at World Heritage Sites: A Practical Manual for World Heritage Site Managers. Paris: World Heritage Centre.

Richardson, M. (1989). "The Artifact as Abbreviated Act: A Social Interpretation of Material Culture." The Meaning of Things: Material Culture and Symbolic Expression (eds.) Hodder I. One World Archaeology Series. Unwin Hyman: London.

Rosenberg, D. (1993). "Imposing Libraries: The Establishment of National Public Library Services in Africa, with Particular Reference to Kenya." World Libraries, Vol. 4, No.I.

http://ojsserv.dom.edu/ojs/index.php/worldlib/article/view/272/228, accessed on 15 February 2016.

Sturges, P. and Neill R. (1998). The Quiet Struggle: Information and Libraries for the People of Africa Second Edition. London: Mansell.

Thomas, N. (200I). "Appropriation/Appreciation: Settler Modernism in Australia and New Zealand." The Empire of Things: Regimes of Value in Material Culture. Oxford: School of American Research Press/Santa Fe and James Currey.

What Objects Do? A Material and Visual Culture Perspective. www.objectretrieval.com/node/266, accessed on 17 May 2016.

Zeleza, P. T. (N.d.) "Banishing the Silences: Towards the Globalisation of African History." http://www.codesria.org/spip.php?article723, accessed on 15 July 2016.

\section{Interviews}

Afuh, William. Bu, 28 December 2012.

Akou, Nathaniel, Bomaka Buea, 13 December 2012.

Asang, Simon Muam Rtd Rev. Bu, 8 January 2007.

Bughe Bei, Dan. Bu, 23 December 2007.

Cheng, E.N.G. Bu Road Wum, 20 March 1997.

Ebuh, Timathias. Bu, 28 December 2002.

Kaghesah, High. Bu, I March 1997.

Kamkoh, James Ambei. Bu, I4 August 2007 and 28 December 2007.

Kom, Andreas. Bu, 20 August 2007; 7 March 2008 and 29 December 2012.

Kpwa, Vincent. Bu, 28 December 2012.

Kpwai Embou, Abel. Ndop, 27 December 2012.

Kpwai Ikai, Joseph. Bu, 28 December 2012.

Ndang, Ebenezar Fung. Bu, 28 December 2012.

Ndeh, Metika, Bu, 20 August 2007.

Ndong, Teacup. Bu, 29 December 2012.

Ndzjuh, Grace. Bomaka Buea, 16 December 2012.

Ngoisey. Bu, 23 December 2008.

Njuh, Simon. Bu, 28 December 2012.

Nyamngoh, Joseph. Bu, 20 August 2007.

Wei, Vida, Bomaka Buea, 17 August 2007 and 16 December 2012. 